Koichi Takahashi

\title{
Effects of wind and thermal conditions on timberline formation in central Japan: a lattice model
}

Received: 20 August 2013/ Accepted: 8 January 2014/Published online: 31 January 2014 (C) The Ecological Society of Japan 2014

\begin{abstract}
The upper distribution limit of tall tree species Abies mariesii is the timberline in central Japan, and dwarf pine Pinus pumila dominates above the timberline to near the summit. My previous studies suggested that the main cause of the timberline formation is the increase in mortality due to strong wind in winter rather than low growth due to low summer temperature. This study evaluated how wind velocity affects timberline formation and if the altitude of timberline moves upward due to high thermal conditions, by using a lattice model. Increase in wind velocity throughout the altitude lowered the altitudes of upper distribution limits of the two species. On the contrary, prolonged growth period due to high thermal conditions increased the upper distribution limit of $P$. pumila, and the upper distribution limit of $A$. mariesii was hardly affected by the change of growth period. However, the upward shift of the upper distribution limit of $P$. pumila due to the prolonged growth period in the model would not be realistic because $P$. pumila had already distributed up to near the summit. This study concludes that $A$. mariesii is a superior competitor to $P$. pumila at low altitudes with low wind velocity, but dwarf pine $P$. pumila can dominate at higher altitudes because $A$. mariesii suffers severe mechanical damage due to strong wind in winter, and that the altitude of the timberline does not move upward even under high thermal conditions due to global warming.
\end{abstract}

Keywords Climatic change - Global warming - Lattice model $\cdot$ Timberline $\cdot$ Treeline

Koichi Takahashi is the recipient of the 6th Yasuyuki Oshima Award.

K. Takahashi $(\bowtie)$

Department of Biology, Faculty of Science, Shinshu University, Matsumoto 390-8621, Japan

E-mail: koichit@shinshu-u.ac.jp

K. Takahashi

Institute of Mountain Science, Shinshu University, Asahi 3-1-1, Matsumoto 390-8621, Japan

\section{Introduction}

Global warming is supposed to largely affect plant growth and vegetation distribution along altitudinal and latitudinal gradients. Especially, the increase in temperature is expected to be greater at high altitudes and latitudes with cold climatic conditions (Bates et al. 2008). Tree growth is limited by low summer temperature in these regions because the tree growth often increases in warm summer years (Buckley et al. 1997; Mäkinen et al. 2002). Therefore, tree growth possibly increases at high altitudes and latitudes by global warming. Global warming also affects vegetation distribution. For example, the altitudinal distribution of ten dominant plant species in California moved upward averaging $65 \mathrm{~m}$ during 30 years (Kelly and Goulden 2008). Plant distribution along an altitudinal gradient (0-2,600 $\mathrm{m}$ above sea level) also moved upward averaging $29 \mathrm{~m}$ per decade during 1905-2005 in west Europe, and this tendency was more conspicuous in the alpine zone (Lenoir et al. 2008). However, reports have described that the altitude of treelines does not change (Paulsen et al. 2000; Juntunen et al. 2002). About half of the treelines in the world show no change of altitude, based on meta-analysis (Harsch et al. 2009). Therefore, assuming that vegetation distribution is determined by only climatic conditions (temperature and precipitation) might be an error. From examination of age and size structures around treelines, some studies speculated that the altitude of treelines moved upward because young seedlings and saplings distributed above the treelines (Batllori and Gutierrez 2008; Sutinen et al. 2012). However, such speculation would be wrong because only younger individuals exist at higher altitudes if mortality is greater at higher altitudes. Therefore, predicting distribution changes of plants would be difficult from a snapshot of age and size structures at a given time.

Treeline physiognomy of Japan differs from that of North America and New Zealand. The growth of tall 
tree species is inhibited at high altitudes and the trees become shrubby krummholz around treelines in North America and New Zealand (Wardle 1968, 1985; Marr 1977). By contrast, tall tree species, such as Abies mariesii Mast. and Betula ermanii Cham., distribute at the upper part of the subalpine zone in Japan, and dwarf pine Pinus pumila Regel scrub distributes above the Abies-Betula forest zone (Miyajima et al. 2007). The upper distribution limit of $P$. pumila scrub is the treeline. The upper distribution limit of tall tree species A. mariesii and $B$. ermanii is the timberline (i.e., the lower distribution limit of $P$. pumila). The physiognomy of vegetation at high elevation in Japan is similar to that in central Europe (Wardle 1977), because dwarf pine Pinus mugo Turra (the same genus as $P$. pumila) dominates at high altitudes (Crawford 2008). Tanaka et al. (2009) and Horikawa et al. (2009) predicted that the distribution area of $A$. mariesii and $P$. pumila in central Japan will shrink to $15-25 \%$ of the current distribution area by the year 2100 , by using a niche-based model (or correlative model) that was constructed from correlations between current distribution area and climatic conditions (temperature and precipitation). Their results mean an upward distribution shift of the timberline and treeline due to global warming.

The scrub height of $P$. pumila was largely reduced to about one-fourth in a slight altitudinal difference of $350 \mathrm{~m}$ from the lower distribution limit $(2,500 \mathrm{~m}$ a.s.1.) to the upper distribution limit $(2,850 \mathrm{~m}$ a.s.l.) on Mount Norikura in central Japan (Takahashi and Yoshida 2009) and was also largely reduced to about one-fifth at a wind-exposed site compared with a wind-protected site at the same altitude (Takahashi 2003). Reduction of scrub height at wind-exposed sites was also observed in Hokkaido, northern Japan (Okitsu and Ito 1983). Snow depth is lower at wind-exposed sites such as ridges and summits than wind-protected sites. Plant tissues above the snow surface are injured by wind-blown ice particles at wind-exposed sites (e.g., cuticle abrasion), which causes winter desiccation (Tranquillini 1979; Hadley and Smith 1983, 1986). The changes of scrub height of $P$. pumila indicate that wind velocity is a main factor affecting community structure at high altitudes. Therefore, the prediction of distribution change of plants is not quite as simple as the niche-based models predicted. Miyajima and Takahashi (2007) investigated mechanical damage of conifers along an altitudinal gradient (800-2,500 m a.s.1.) on Mount Norikura in central Japan; mechanical damage of conifers suddenly increased at about 2,200 $\mathrm{m}$ a.s.l. rather than a gradual increase with altitude. This suggests that mechanical damage of conifers increases when wind velocity exceeds a threshold (Peltola et al. 1999). Takahashi et al. (2012) examined the mechanism of the timberline formation (i.e., the upper distribution limit of $A$. mariesii) on Mount Norikura from permanent-plot data. Although the growth rate of $A$. mariesii did not change from the upper part of the developed forest $(2,350 \mathrm{~m}$ a.s.1.) to the timberline (2,500 m a.s.1.), the trunk height of $A$. mariesii largely decreased to about one-third in the slight altitudinal difference of $150 \mathrm{~m}$ and the mortality increased three times by mechanical damage due to disturbances. This tendency was more conspicuous by larger individuals. Wind velocity is greatest in winter throughout the year near the summit of Mount Norikura (Saito and Irie 2002). Therefore, the main cause of timberline formation on Mount Norikura is mechanical damage in winter rather than low summer temperature insufficient for growth. It is suggested that strong wind in winter largely affects the timberline formation more in central Japan than other regions in Japan (Yoshino 1973). The altitudinal location of the timberline is suggested not to rise under climatic warming conditions because strong wind in winter is the main cause of timberline formation (Takahashi et al. 2012), as opposed to the prediction by the niche-based model.

The aims of this study were to show (1) how wind velocity affects timberline formation, and (2) if the altitudinal location of the timberline does not move upward even under global warming as predicted by Takahashi et al. (2012). For these aims, this study used a lattice model.

\section{Outline of model}

In the model, I represent an altitudinal change of forest structure and dynamics by a lattice of width $100 \times$ height 500 cells, where width and height are horizontal and altitudinal directions, respectively. A coordinate of each cell is denoted as $(i, j)$, where $i$ and $j$ are a horizontal coordinate (1-100) and an altitudinal coordinate (1-500), respectively. Generally, wind velocity is greater at higher altitudes (Araki 1995). For simplicity, this model assumes that wind velocity increases linearly with altitude as:

$w_{j}=0.5 \times j / 500$

where $w_{j}$ is a relative value of wind velocity (dimensionless) at an altitudinal coordinate $j$. Each cell is occupied by $P$. pumila, A. mariesii, or bare ground. An individual tree at each cell grows in trunk height or dies at each time step (year), and a new individual tree recruits at a vacant cell. Height growth, mortality and recruitment process are as follows.

This study used a multiplicative growth model in which growth is equal to the maximum potential growth reduced by a series of modifiers. Trunk height growth rate $G(i, j, t)\left(\mathrm{m} \mathrm{year}^{-1}\right)$ at a coordinate $(i, j)$ at time $t$ (year) is given by the following equation:

$$
\begin{aligned}
G(i, j, t)= & a_{0} \times\left(1-\frac{a_{1} \times \mathrm{NN}(i, j, t)}{(2 \times \mathrm{ND}+1)^{2}-1}\right) \\
& \times\left(1-\frac{H(i, j, t)}{H_{\max }}\right) \times\left(1-w_{j}\right) \\
& \times(1-0.001 \times j)
\end{aligned}
$$

where $a_{0}\left(\mathrm{~m}\right.$ year $\left.{ }^{-1}\right)$ is the maximum growth rate, $a_{1}$ (dimensionless) is a sensitivity parameter to suppression 
$(0-1.0), H(i, j, t)(\mathrm{m})$ is trunk height at a coordinate $(i, j)$ at time $t, H_{\max }(\mathrm{m})$ is the maximum trunk height, NN $(i, j, t)$ is the number of neighboring trees taller than a target tree at a coordinate $(i, j)$ at time $t$. Neighborhood distance (ND) was defined as two cells from the target cell. In this equation, it is assumed that trunk height growth rate decreases from the maximum growth rate with increasing the number of taller neighboring trees and wind velocity and with approaching the maximum trunk height. The growth rate is reduced at high altitudes with decreasing growth period (Takahashi 2010). Therefore, a parameter, $(1-0.001 \times j)$ was inserted at the right side of the equation to shorten the growth period at high altitudes.

Mortality was assumed to be increased by competition and mechanical damages due to strong wind (Takahashi 2010; Takahashi et al. 2012). Mortality $M(i, j, t)$ $\left(\right.$ year $^{-1}$ ) at a coordinate $(i, j)$ at time $t$ is given by the following equation:

$$
\begin{aligned}
M(i, j, t)= & b_{0}+b_{1} \times \frac{\mathrm{NN}(i, j, t)}{(2 \times \mathrm{ND}+1)^{2}-1}+b_{2} \times w_{j}+b_{3} \\
& \times w_{j} \times \frac{\mathrm{NN}(i, j, t)}{(2 \times \mathrm{ND}+1)^{2}-1}
\end{aligned}
$$

where $b_{0}\left(\right.$ year $\left.^{-1}\right)$ is a minimum mortality, $b_{1}\left(\right.$ year $\left.^{-1}\right)$ is the sensitivity of mortality to suppression by local crowding of taller neighboring trees, $b_{2}\left(\right.$ year $\left.^{-1}\right)$ is the sensitivity of mortality to wind velocity, $b_{3}\left(\right.$ year $\left.^{-1}\right)$ is a parameter of wind-protection effect by taller neighboring trees. Mechanical damage of $A$. mariesii is suggested to increase if wind velocity exceeds a threshold (Miyajima and Takahashi 2007). Thus, this model assumes that mechanical damage occurs if $w_{j}$ is greater than or equal to 0.2 (i.e., $b_{2}=b_{3}=0$ in the case of $w_{j}<0.2$ ). Whether an individual tree of each cell at time $t$ dies or not was determined as follows. A random number $(0-1.0)$ is generated for each cell at time $t$. An individual tree in the cell dies if the random number is smaller than $M(i, j, t)$, then the cell becomes a vacant cell (the state of bare ground).

A vacant cell will be occupied by $P$. pumila or A. mariesii at the next time step, or will be left as a vacant cell. The number of each species enabling reproduction is counted within the neighborhood area (total 24 cells) for each vacant cell. If the number of trees enabling reproduction is $>15$ for either species $P$. pumila or $A$. mariesii, that species will occupy the vacant cell. If the number of trees enabling reproduction is $<15$ within the range in neither species, that cell will be a vacant cell again at the next time step.

Maximum trunk heights of $P$. pumila and A. mariesii were set as 2 and $20 \mathrm{~m}$, respectively (Miyajima and Takahashi 2007; Takahashi and Yoshida 2009). Minimum trunk height enabling reproduction was set as $0.5 \mathrm{~m}$ for P. pumila (Okitsu and Mizoguchi 1991). Unfortunately, no information was available for the reproductive onset of $A$. mariesii in central Japan. It is reported that trunk height of $A$. mariesii enabling reproduction was shorter at higher altitudes on Mount Hakkoda in northern Japan (Sakai et al. 2003), such trend was not observed at Mount Norikura (personal observation). Trunk height at reproductive onset positively correlates with the maximum trunk height (Thomas 1996). The reproductive onset of $A$. mariesii was determined as trunk height of $10 \mathrm{~m}$, according to the compiling data (Thomas 2011).

Each parameter of growth and mortality models was determined after trial and error by considering speciesspecific traits (Table 1). The sensitivity parameter to suppression $\left(a_{1}\right.$, dimensionless) in the growth model was set to be greater for $P$. pumila (1.0) than for $A$. mariesii (0.5) because $P$. pumila and $A$. mariesii are shade-intolerant and shade-tolerant species, respectively (Kohyama 1983; Takahashi 2003). Unfortunately, no data were available for height growth rate of $A$. mariesii, except for small saplings shorter than $1 \mathrm{~m}$ (Kohyama 1980). It is difficult to apply the sapling growth rate to the whole range of tree size because sapling growth rate is smaller than taller trees (Takahashi 1996, 1997). Therefore, the maximum height growth rate $\left(a_{0}, \mathrm{~m} \mathrm{year}^{-1}\right)$ of A. mariesii was determined as $0.25 \mathrm{~m}_{\text {year }}{ }^{-1}$, according to the height growth rate of other Pinaceae species Abies sachalinensis and Picea glehnii with trunk height between 5 and $10 \mathrm{~m}$ (Takahashi 1996). Although the maximum shoot elongation rate of Pinus pumila is about $0.1 \mathrm{~m}$ year $^{-1}$ at the lower distribution limit (Takahashi and Yoshida 2009), the maximum height growth rate of $P$. pumila was determined as $0.15 \mathrm{~m}_{\text {year }}{ }^{-1}$ because $P$. pumila distributes in higher altitudes than $A$. mariesii and because height growth rate is decreased in high altitudes by multiplying $\left(1-w_{j}\right)$ and $(1-0.001 \times j)$ in the model.

Given the difference in longevity between $P$. pumila (ca. 100 years) and A. mariesii (ca. 200 years) (Natori and Matsuda 1966; Takahashi et al. 2011), the minimum mortality $\left(b_{0}\right.$, year $\left.^{-1}\right)$ of $A$. mariesii $(0.0025)$ was determined as half that of $P$. pumila (0.005). The sensitivity parameter to suppression $\left(b_{1}\right.$, year $\left.^{-1}\right)$ was also set to be greater for P. pumila (0.05) than for A. mariesii (0.01), like the growth model. Existence of taller neighbors than a target tree possibly both intensifies and weakens the mortality of the target tree. The mortality of target trees is increased by mechanical damage due to strong wind $\left(b_{2}\right.$, year $\left.^{-1}\right)$, while the mortality is weakened by a greater

Table 1 Parameters for trunk height growth and mortality of Pinus

\begin{tabular}{|c|c|c|}
\hline Parameter & P. pumi & A. mariesii \\
\hline Growth rate $\left(\mathrm{m}\right.$ year $\left.{ }^{-1}\right)$ & & \\
\hline$a_{0}$ Maximum growth rate $\left(\mathrm{m}\right.$ year $\left.{ }^{-1}\right)$ & 0.15 & 0.25 \\
\hline$a_{1}$ Sensitivity to suppression (dimensionless) & 1.0 & 0.5 \\
\hline Mortality $\left(\right.$ year $\left.^{-1}\right)$ & & \\
\hline$b_{0}$ Minimum mortality $\left(\right.$ year $\left.^{-1}\right)$ & 0.005 & 0.0025 \\
\hline$b_{1}$ Sensitivity to suppression $\left(\right.$ year $\left.^{-1}\right)$ & 0.05 & 0.01 \\
\hline$b_{2}$ Sensitivity to wind $\left(\right.$ year $\left.^{-1}\right)$ & 0.03 & 0.05 \\
\hline$b_{3}$ Wind-protection effect $\left(\right.$ year $\left.^{-1}\right)$ & -0.01 & -0.03 \\
\hline
\end{tabular}
pumila and Abies mariesii in the lattice model 
number of taller neighbors because of the wind-protection effect $\left(b_{3}\right.$, year $\left.^{-1}\right)$. Therefore, the absolute difference between the parameters $b_{2}$ and $b_{3}$ is important for the effect of wind on the mortality. Mortality of $A$. mariesii increases around the timberline because of mechanical damage due to strong wind in winter (Takahashi et al. 2012). Although the trunk height and shoot elongation of dwarf pine $P$ pumila also decrease at windy ridges and slopes near the upper distribution limit (Takahashi 2003; Takahashi and Yoshida 2009), P. pumila is protected from strong wind by snow accumulation around the timberline. Thus, in this model, the absolute difference between the two parameters was set to be greater for A. mariesii $\left(b_{2}=0.05, b_{3}=-0.03\right)$ than for $P$. pumila $\left(b_{2}=0.03, b_{3}=-0.01\right)$. The maximum mortality is 0.065 for $P$. pumila and 0.0225 for A. mariesii for the parameter sets of the two species.

For initial conditions, an equal number of each species (i.e., 25,000 cells) was randomly assigned in the community $(100 \times 500$ cells $)$. Trunk height of each species in each cell was randomly determined within the ranges $0.1-20.0 \mathrm{~m}$ for $A$. mariesii and $0.1-2.0 \mathrm{~m}$ for $P$. pumila. Each simulation ran until convergence, which is defined as changes smaller than 100 in the number of cells of each species in 100 consecutive time steps. The program was coded in $\mathrm{C}++$, and was compiled by using freeware MinGW.

\section{Simulation analysis}

Simulation was done by changing the wind velocity and thermal condition to examine the effects of wind velocity and thermal condition on the altitudinal distribution of $A$. mariesii and $P$. pumila. The wind velocity was changed by multiplying the parameter of wind velocity along an altitudinal gradient $(0.5 \times j / 500$, where $j$ ranges between 1 and 500) by coefficients $0.7-1.3$ at 0.1 intervals. Although this model does not treat a thermal condition as a variable, the thermal condition affects the growth period in the model. Therefore, the change of the thermal condition was expressed by multiplying the parameter of growth period along an altitudinal gradient $(1-0.001 \times j)$ by coefficients $0.7-1.3$ at 0.1 intervals.

For each multiplier of the wind velocity and growth period, ten replicate simulations were run until convergence. The variation in species distribution in a horizontal direction was small among the ten replicates. For example, in the case of the multiplier 1.0 for both wind velocity and growth period, the mean number with standard deviation for $A$. mariesii in a horizontal direction in the lattice of $100(i) \times 500(j)$ cells among ten replicates was almost $100 \pm 0$ between $j 1$ and 194, and decreased from $99.8 \pm 0.4(j$ 195) to $0.4 \pm 0.8(j 201)$. Under the same condition, the mean number of $P$. pumila increased from $0.2 \pm 0.6(j$ 198) to $99.7 \pm 0.7$ ( $j$ 202), and almost $100 \pm 0$ above $j 203$ until $j$ 387, and then decreased from $99.9 \pm 0.3(j$ 388) to $0.3 \pm 0.9$ ( $j$ 415).

The upper distribution limit of each species was determined as follows. The highest altitudinal coordinate $(j)$ to which each species distributes was determined for each altitudinal line with the same horizontal coordinate (i) (i.e., a total of 100 altitudinal lines). The 100 highest altitudinal coordinates of each species were averaged for each simulation. Then, the upper distribution limit was determined by averaging the mean highest altitudinal coordinates among ten replicates of simulation.

The mean trunk height of each species along an altitudinal gradient was calculated by averaging trunk height among the cells that the species occupied in each horizontal line of the same altitudinal coordinate $(j)$ (i.e., a total of 500 horizontal lines). The number of cells of each species at each horizontal line decreases near the upper distribution limit. To avoid large variation due to the small number of individual trees at each horizontal line, the mean trunk height at each horizontal line was not calculated for each species if the number of cells of a species was $<15$. The mean trunk height of each species along the altitude was determined by averaging the mean trunk height of each horizontal line of the same altitudinal coordinate $(j)$ among ten replicates of simulation.

\section{Results}

\section{Altitudinal distribution of two species}

An example of the change of the number of cells (trees) with time was shown using the basic parameter set of each species (Fig. 1). I assigned about 25,000 of each species randomly at the initial condition $(t=0)$ (Fig. 2a). The number of cells of each species decreased soon after the start of simulation (Fig. 1). This tendency

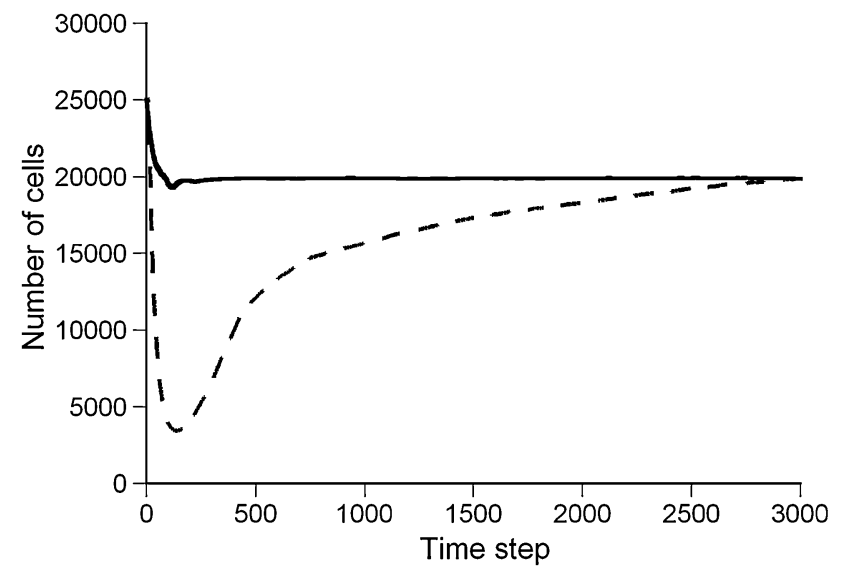

Fig. 1 Time course of the number of cells of Abies mariesii (solid line) and Pinus pumila (broken line) 
(a) $t=0$

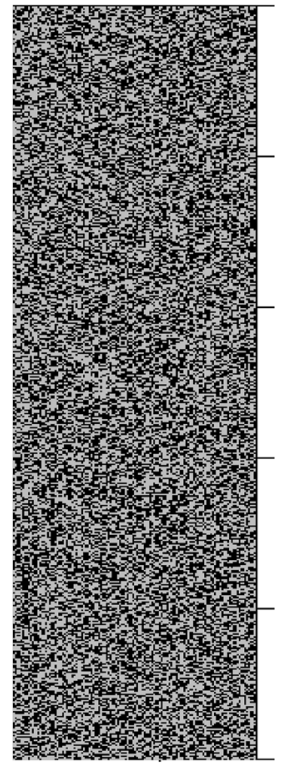

(e) $t=200$

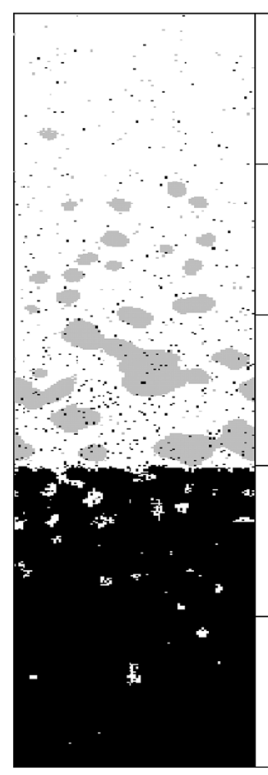

(b) $t=10$

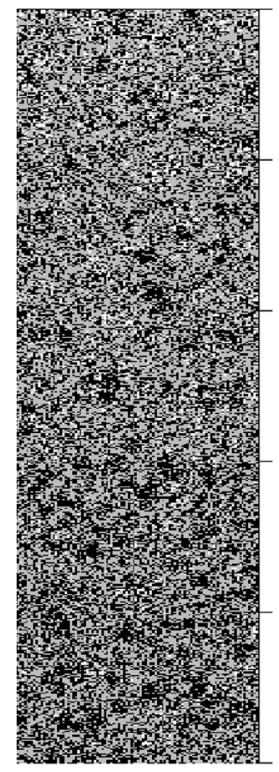

(f) $t=500$

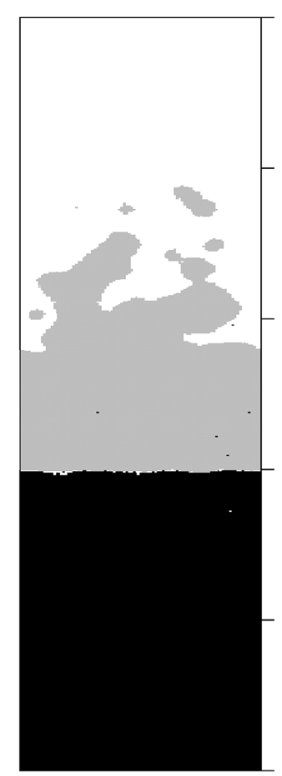

(c) $t=50$

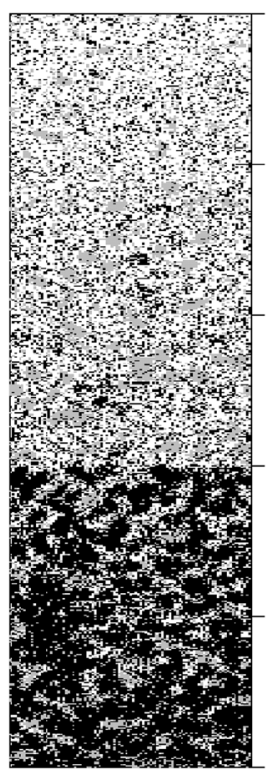

(g) $t=1000$

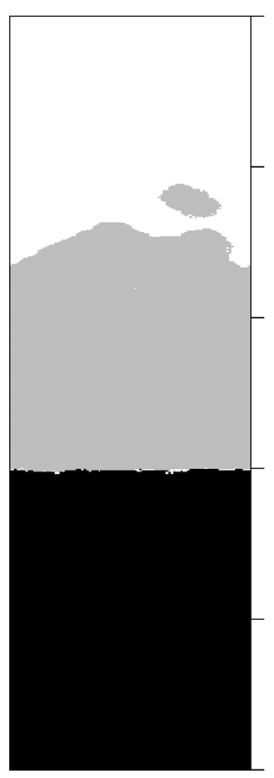

(d) $t=100$

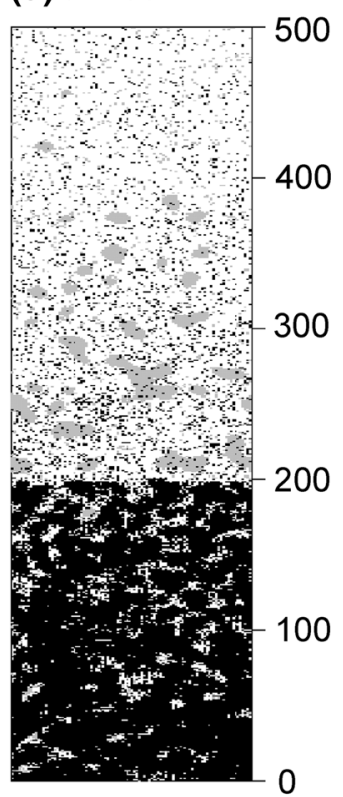

(h) $t=3000$

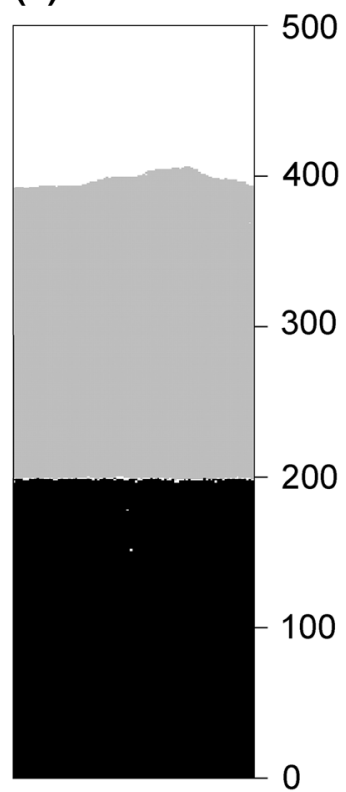

Fig. 2 Spatial distribution of Abies mariesii (black) and Pinus pumila (gray) along an altitudinal gradient at a time $t=0$, b $t=10$, $\mathbf{c} t=50, \mathbf{d} t=100$, e $t=200, \mathbf{f} t=500, \mathbf{g} t=1,000$ and $\mathbf{h} t=3,000$

was more conspicuous for $P$. pumila. The large reduction of shade-intolerant dwarf pine $P$. pumila (inferior competitor) was caused by interspecific competition with shade-tolerant tall tree $A$. mariesii (superior competitor) because the two species distributed closely at the initial condition (Fig. 2a). The number of A. mariesii was almost constant after time step 100. The number of $P$. pumila largely decreased to 3,460 at time step 130 , and then the number of $P$. pumila gradually increased (Fig. 1). A. mariesii began not to distribute above coordinate 200 of the altitudinal axis from time step 50 (Fig. 2c). The number of $P$. pumila decreased below coordinate 200 of the altitudinal axis because of the interspecific competition with $A$. mariesii, but it began to increase above coordinate 200 of the altitudinal axis from time step 100. The distribution of the two species began to separate at about coordinate 200 of the altitudinal axis at time step 200. P. pumila gradually expanded its distribution area at high altitudes. Finally, the number of cells converged at time step 3,000, and the upper distribution limit of $P$. pumila was about coordinate 400 of the altitudinal axis (Fig. 2h). Why A. mariesii cannot distribute above coordinate 200 of the altitudinal axis is that tall tree species $A$. mariesii tends 


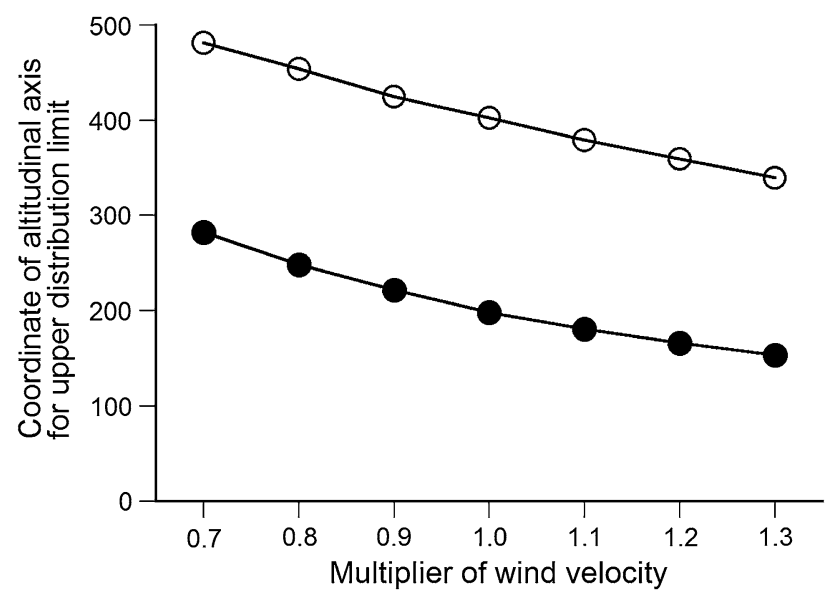

Fig. 3 Changes of the upper distribution limits of Abies mariesii (solid circle) and Pinus pumila (open circle) along multipliers of wind velocity. Only mean values of ten replicates of simulation are shown because the variation was small. Mean standard deviations were 6.4 and 1.6 for A. mariesii and P. pumila, respectively

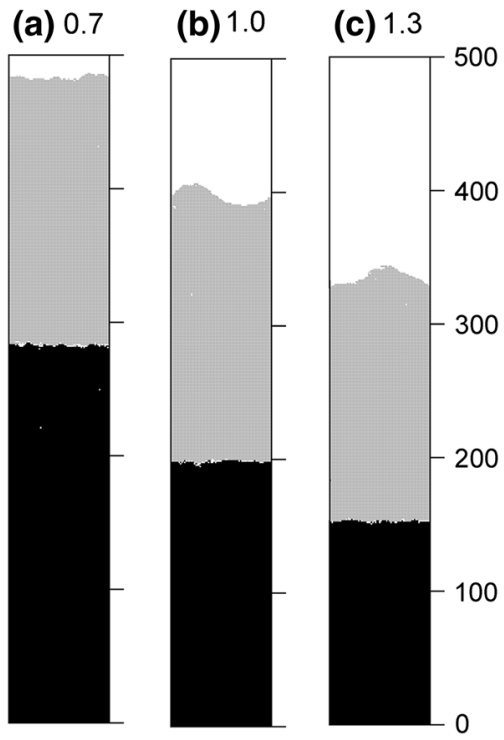

Fig. 4 Spatial distribution of Abies mariesii (black) and Pinus pumila (gray) along an altitudinal gradient for three multipliers of wind velocity, a 0.7 , b 1.0 , and c 1.3 to be damaged by strong wind compared with $P$. pumila. The wind velocity was 0.2 at coordinate 200 , which is the threshold that $A$. mariesii dies of mechanical damages due to strong wind. However, the spatial distribution of the two species clearly separated at about coordinate 75 of the altitudinal axis even if a threshold of wind velocity was not set, and the upper distribution limit of $P$. pumila was about 400 , which was the same as the upper distribution limit calculated by the model with the threshold of wind velocity for mechanical damage of $A$. mariesii (data not shown).

Effects of wind velocity and thermal condition on altitudinal distribution

The effect of wind velocity on the altitudinal distribution of the two species was examined. The upper distribution limit of the two species decreased with an increase in the multiplier of wind velocity (Figs. 3, 4). As the multiplier of wind velocity was lower, the mean trunk height of A. mariesii tended to be taller at a given coordinate of the altitudinal axis above coordinate 100 (Fig. 5a). The trunk height of $A$. mariesii at the upper distribution limit was about $10 \mathrm{~m}$, irrespective of the multiplier of wind velocity. This trunk height is the minimum reproductive size of $A$. mariesii. The change of trunk height of $P$. pumila by the multiplier of wind velocity was somewhat different from $A$. mariesii. As the multiplier of wind velocity was higher, the trunk height of $P$. pumila was lower at a given coordinate of the altitudinal axis (Fig. 5b). Absolute change of wind velocity due to the multiplier was greater at higher altitudes. Therefore, the relative change of trunk height by the change of multiplier of wind velocity is considered to be greater for $P$. pumila distributing at higher altitudes than for A. mariesii.

I examined the effect of thermal condition expressed as length of growth period on the altitudinal distribution of the two species. Although the upper distribution limit of $P$. pumila moved upward as the multiplier of growth period increased, the upper distribution limit of A. mariesii was almost constant (coordinate 200 of the
Fig. 5 Altitudinal changes of trunk height of a Abies mariesii and b Pinus pumila for three multipliers of wind velocity, 0.7 (black), 1.0 (gray), and 1.3 (open). Only a mean value of each altitudinal coordinate is shown. Mean standard deviations of trunk height at each altitudinal coordinate were about 0.7 and 0.07 for $A$. mariesii and $P$. pumila, respectively

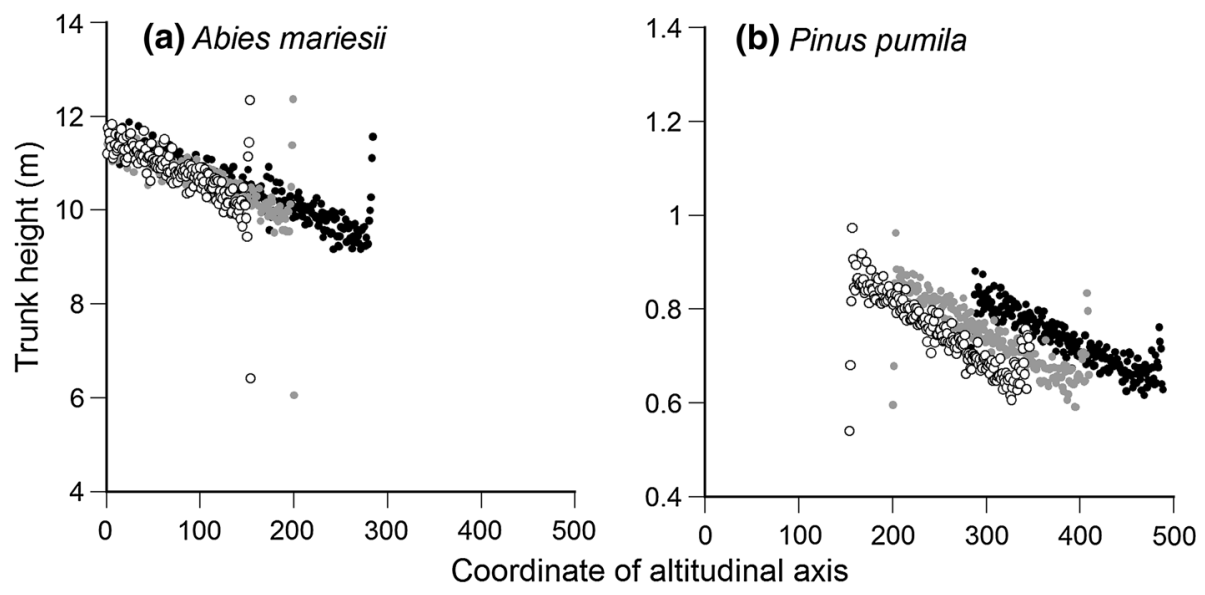




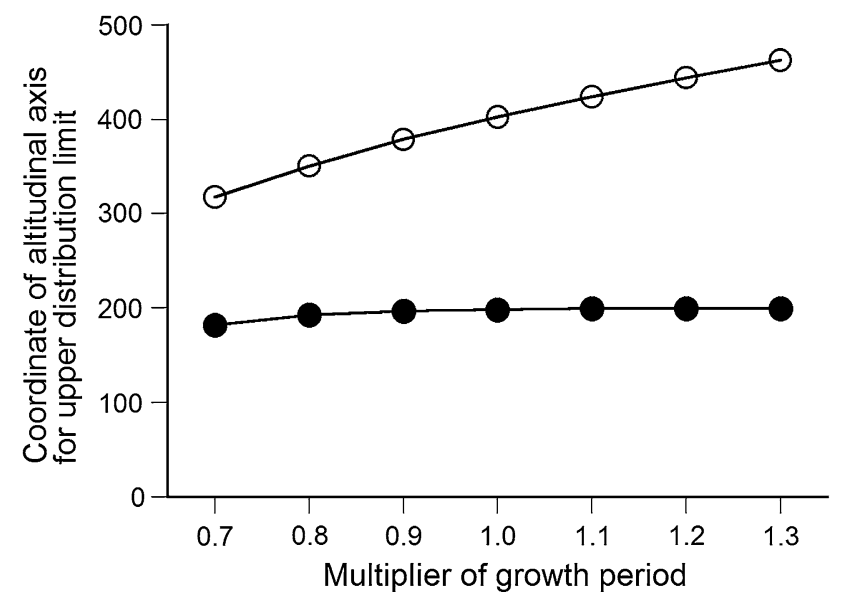

Fig. 6 Changes of the upper distribution limits of Abies mariesii (solid circle) and Pinus pumila (open circle) along multipliers of a growth period. Only mean values of ten replicates of simulation are shown because the variation was small. Mean standard deviations were 6.4 and 1.6 for $A$. mariesii and $P$. pumila, respectively

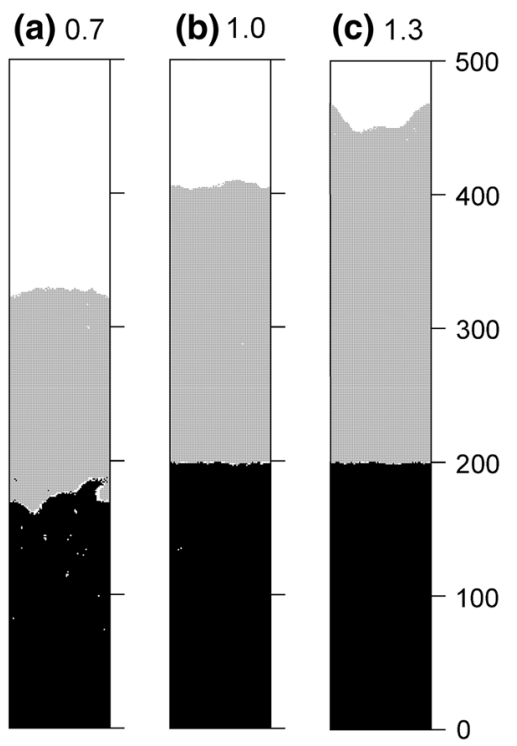

Fig. 7 Spatial distribution of Abies mariesii (black) and Pinus pumila (gray) along an altitudinal gradient for three multipliers of a growth period, a 0.7, b 1.0 , and c 1.3 altitudinal axis), irrespective of the multiplier (Figs. 6, 7). The upper distribution limit of $A$. mariesii at multiplier 0.7 was almost the same as that at the other values of the multiplier, and the dominance of A. mariesii around the timberline (i.e., the upper distribution limit of $A$. mariesii) was somewhat lower than the other multipliers of the growth period because $P$. pumila partly dominated below coordinate 200 of the altitudinal axis (Fig. 7a). As the growth period decreased, the trunk height of the two species decreased at a given coordinate of the altitudinal axis (Fig. 8).

\section{Discussion}

Using a lattice model, this study showed (1) that A. mariesii is a competitively superior species to $P$. pumila at low altitudes with low wind velocity, but $P$. pumila can dominate at high altitudes because $A$. mariesii cannot increase its trunk height due to mechanical damage by strong wind at high altitudes, and (2) that the timberline (i.e., the upper distribution limit of $\mathrm{A}$. mariesii) does not move to upward even in high thermal conditions because mechanical damage due to strong wind largely affects the timberline formation. These results are consistent with the prediction of Takahashi et al. (2012), i.e., the timberline is formed by the abrupt increase in mortality due to strong wind in winter, although the growth of $A$. mariesii does not decrease from the upper part of developed forest stand (2,350 m a.s.1.) to the timberline $(2,500 \mathrm{~m}$ a.s.1.) on Mount Norikura in central Japan.

Effects of strong wind in winter and global warming on altitudinal distribution of two species

The warmth index (WI) is an index that expresses the relationship between vegetation distribution and thermal conditions in the world (Kira 1948). A WI of $15^{\circ} \mathrm{C}$ months is the boundary between the subalpine zone and alpine zone. For Mount Norikura in central Japan, a WI of $15{ }^{\circ} \mathrm{C}$ months is consistent with $2,800 \mathrm{~m}$ a.s.l., which
Fig. 8 Altitudinal changes of trunk height of a Abies mariesii and $\mathbf{b}$ Pinus pumila for three multipliers of growth period, 0.7 (black), 1.0 (gray), and 1.3 (open). Mean standard deviations of trunk height at each altitudinal coordinate were about 0.7 and 0.07 for $A$. mariesii and P. pumila, respectively

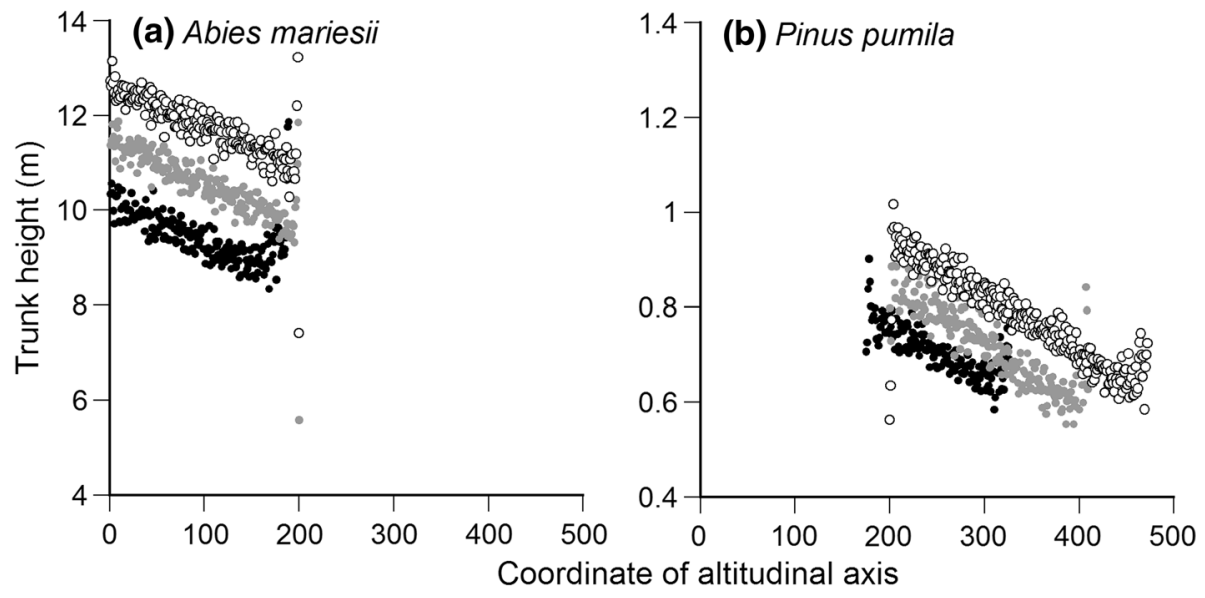


is the upper distribution limit of $P$. pumila (Miyajima et al. 2007). Therefore, the upper distribution limit of $P$. pumila may move upward by global warming. Dullinger et al. (2004) examined the effects of global warming on the distribution of a dwarf pine (Pinus mugo), which is a life form similar to $P$. pumila of this study. They predicted that the cover of $P$. mugo will increase from $10 \%$ at present to $24-59 \%$ after 1,000 years. In this study, the distribution area of $P$. pumila expanded to a higher elevation if the length of the growth period was prolonged (i.e., high multiplier of growth period). However, saying that the distribution area of $P$. pumila will expand by global warming would be untrue because $P$. pumila has already distributed up to near the summits of many high mountains. The model of this study also did not take edaphic conditions into account. The ground substrate becomes rubble near summits. $P$. pumila cannot distribute on such rubble slopes without a developed soil layer (unpublished data). Therefore, $P$. pumila may not be able to expand its distribution area upward even under global warming.

Many simulation studies have been done to predict the effects of global warming on plant distribution using niche-based models (or correlated models) from correlations between the current distribution area and climatic conditions, such as monthly mean temperature and monthly sum of precipitation (Iverson and Prasad 1998; Thuiller et al. 2005). Previous studies by niche-based models reported that global warming will increase risk of extinction of many plant species at the current distribution area because the distribution area of these plant species will move to higher altitudes and latitudes (Guisan and Theurillat 2000; Berry et al. 2003; Dirnböck et al. 2003; Casalegno et al. 2010). However, their results were derived from the assumption of the model, and so the risk of extinction is a foregone conclusion. Although nichebased models can predict distribution changes of many plant species on a large scale, the results of the niche-based model show only the movement of climatic conditions of the current distribution area rather than the distribution changes of the plant species. On the contrary, in a predictive study that used a process-based model incorporating the life-history traits of plant species, the distribution change of the plant species was less than by the niche-based model (Morin and Thuiller 2009). Therefore, niche-based models possibly overestimate distribution changes of plant species. However, investigating factors that limit the distribution of plant species in the field and incorporating them into a model for precise prediction is necessary, even for the process-based model.

Although the lattice model of this study is simple, it was constructed from the results of my field research. Three important topics can be discussed from the results of this study.

1. Strong wind in winter as a major factor of timberline formation: Although this study treated the timberline (i.e., the upper distribution limit of tall tree species) as a main topic, treeline is also an important transitional ecotone between closed forest and the treeless alpine zone. Three treeline types (Harsch et al. 2009) are (1) the diffuse type characterized by decreasing tree density with increasing altitude; (2) the abrupt type characterized by a continuous canopy with no decline in density right up to the treeline; (3) the krummholz type in which the treeline may be diffuse or abrupt, but is characterized by severely stunted trees. By using meta-analysis, Harsch et al. (2009) reported that the altitude of diffuse-type treelines moves upward by global warming, while that of abrupt and krummholz types does not change. The diffuse-type treeline is formed by low temperature insufficient for growth (Harsch and Bader 2011). By contrast, if trees can grow at the treeline, but cannot increase the trunk height because of disturbance by strong wind and snow, the treelines of the abrupt and krummholz types are formed. Much physical damage, such as broken stems, are often observed at treelines in northern Europe (Hofgaard et al. 1991), suggesting the importance of strong wind on treeline formation. The altitude of treelines has not risen at wind-exposed sites in the last century, while the treeline has moved upward at wind-protected sites (Kullman and Öberg 2009; Kullman 2010). The timberline is $200-500 \mathrm{~m}$ below the summits of many mountains in Hokkaido, northern Japan, irrespective of thermal conditions (Okitsu and Ito 1984). Therefore, the altitude of the timberline moving upward under global warming is implausible, as predicted by the model of this study.

2. Trade-off between competitive ability and adaptation to high altitude: Shade-intolerant dwarf pine $P . p u$ mila is inferior to tall tree species. Although P. pumila can physiologically distribute at altitudes lower than the timberline, it cannot grow and survive at low altitude because of suppression by tall tree species (Takahashi 2003). However, tall tree species, such as A. mariesii, cannot distribute at high altitudes because of mechanical damage. Actually, many A. mariesii trees show the flagged crown form at the timberline on Mount Norikura (Wardle 1977; Nakamoto et al. 2013). This crown form is caused by strong wind in winter (Scott et al. 1987). By contrast, $P$. pumila is hardly damaged by strong wind in winter because its creeping trunk is protected by snow accumulation, except for wind-exposed ridges (Nagano et al. 2009; Nakamoto et al. 2012). Although the creeping trunk form is disadvantageous for competition for light because of its low vertical height growth rate per trunk length, it is adaptive to high altitudes (i.e., easily buried under snow and rising up the next spring). Therefore, the distribution of $P$. pumila is suggested to be restricted to high altitudes where $A$. mariesii cannot distribute.

3. Effects of global warming on tree growth and altitudinal location of the timberline: Dendrochronological studies reported that tree growth is reduced by low summer temperature at high altitudes and latitudes (Savva et al. 2006; Massaccesi et al. 2008; Peng et al. 
2008; Fan et al. 2009). The same is true at high altitudes in central Japan (Takahashi 2003; Takahashi et al. 2003, 2005, 2011). Especially, shoot growth of $P$. pumila has a clear positive correlation with summer temperature of the previous year (Takahashi 2006). Takahashi (2005) experimentally showed the increase in shoot growth of $P$. pumila by artificial warming. Therefore, low summer temperature (or short growth period) is assumed to limit annual photosynthetic production of $P$. pumila (Kajimoto 1995). Takahashi and Okuhara (2013) predicted that tree growth at high altitudes in central Japan will increase by global warming, using a simulation model based on the relationships between past growth and climatic conditions. This prediction was also confirmed by the model of this study (i.e., the increase in trunk height at a given coordinate of the altitudinal axis with increasing multiplier of the growth period). Other studies also showed that tree density and biomass production increased at timberlines from the past to the present, although the altitudinal location of timberlines and treelines did not change (Camarero and Gutierrez 2004; Zhang et al. 2009; Liang et al. 2011). For example, increase in biomass production was recognized for $26.7 \%$ of tree species examined by using meta-analysis (Lin et al. 2010). Given that tree growth is limited by low summer temperature at high altitudes and that the main causal factor of timberline formation is disturbance due to strong wind in winter, the results of these previous studies (i.e., the increase in biomass production and non-change of altitudinal location of timberlines) can be explained. Therefore, the results of the lattice model of this study would contribute to understand the effects of global warming on timberlines in other regions.

\section{Regional differences in timberline formation}

It is possible that factors other than strong wind in winter largely affect the timberline formation. For example, coniferous trees are often damaged by snow pressure in Tohoku District, northern Japan (Yamanaka et al. 1973; Ishizuka 1981). Kajimoto et al. (2002) and Seki et al. (2005) found that mechanical breakage of branches and stems by snow settlement and creep occurred in many $A$. mariesii trees in a much more snowy winter than the average at the timberline on Mount Yumori in northern Tohoku District, and that the growth and survival of damaged trees decreased in the subsequent years. They concluded that mechanical damage by snow settlement and creep was the primary factor affecting the timberline formation and wind-related stresses (e.g., winter desiccation, abrasion due to wind-blown ice particles, frost damage) were the secondary factor because mechanical damage due to snow settlement and creep was more frequently observed at their study site than mechanical damage due to strong wind in winter. Although the mechanical damage due to snow settlement and creep is found at the timberline on Mount Norikura (personal observation), many A. mariesii trees are conspicuously flagged, indicating a strong wind stress in winter (Wardle 1977). Shoot dieback of trunk top, another mechanical damage due to strong wind in winter (Ishizuka 1981), was also often observed in many A. mariesii trees at the timberline on Mount Norikura (unpublished data). Furthermore, flagged A. mariesii trees often show the branch-lacking layer that is caused by abrasion due to wind-blown ice particles above snow surface. Especially, abrasion damage is greater near the soil surface because the size of ice particles is greater (Scott et al. 1993). Damaged trees due to strong wind in winter are more often found at the timberline in central Japan, which is situated on the Sea of Japan side and has much snowfall, compared with the Pacific side with less snowfall and Tohoku District (Yoshino 1973). Probably, the most primary factor affecting timberline formation differs according to the regional climatic conditions.

\section{Conclusions}

This study showed that (1) the tall tree species A. mariesii is competitively superior to dwarf pine $P$. pumila at low altitudes with low wind velocity, but $A$. mariesii suffers from severe mechanical damage due to strong wind in the winter, which enables $P$. pumila to dominate at high altitudes, and (2) that the altitudinal location of the timberline does not move upward even if the air temperature increases (i.e., prolonged growth period in the model). The prediction of vegetation changes by niche-based models is no more than the movement of climatic conditions of the current distribution area for plant species. By contrast, to detect the main causal factors affecting vegetation distribution and to predict effects of global warming on vegetation, I conducted field and simulation studies along an altitudinal gradient on Mount Norikura in central Japan from various aspects, such as altitudinal changes of vegetation, forest structure and regeneration, relationships between climatic conditions and tree growth, ecophysiological studies, mechanisms of the timberline and treeline formation, and forecasting tree growth along an altitudinal gradient under climatic change scenarios. Although my study is a case study on Mount Norikura, responses to global warming possibly differ among plant species and ecosystems. Therefore, accumulating much case-study data is important for predicting vegetation responses to global warming precisely on a large scale.

Acknowledgments I thank the many students who belonged to my lab for collaboration of the Norikura project. I am also grateful to Profs. Konno Y, Kohyama T, Hara T, and Lechowicz MJ for instruction when I was an undergraduate and graduate student, 
postdoctoral fellow, and when I stayed at McGill University. This manuscript was improved by comments from anonymous reviewers. This study was partially supported by grants from the Ministry of Education, Culture, Sports, Science and Technology, Japan.

\section{References}

Araki M (1995) Forest meteorology. Kawashima Shoten, Tokyo (in Japanese)

Bates BC, Kundzewicz ZW, Wu S, Palutikof JP (eds) (2008) Climate change and water. Technical Paper of the Intergovernmental Panel on Climate Change. IPCC Secretariat, Geneva

Batllori E, Gutierrez E (2008) Regional tree line dynamics in response to global change in the Pyrenees. J Ecol 96:1275-1288

Berry PM, Dawson TP, Harrison PA, Pearson R, Butt N (2003) The sensitivity and vulnerability of terrestrial habitats and species in Britain and Ireland to climate change. $\mathbf{J}$ Nat Conserv $11: 15-23$

Buckley BM, Cook ER, Peterson MJ, Barbetti M (1997) A changing temperature response with elevation for Lagarostrobos franklinii in Tasmania, Australia. Clim Change 36:477-498

Camarero JJ, Gutierrez E (2004) Pace and patterns of recent treeline dynamics: response of ecotones to climatic variability in the Spanish Pyrenees. Clim Change 63:181-200

Casalegno S, Amatulli G, Camia A, Nelson A, Pekkarinen A (2010) Vulnerability of Pinus cembra L. in the Alps and the Carpathian mountains under present and future climates. For Ecol Manag 259:750-761

Crawford RMM (2008) Plants at the margin. Cambridge Univ Press, Cambridge

Dirnböck T, Dullinger S, Grabherr G (2003) A regional impact assessment of climate and land-use change on alpine vegetation. J Biogeogr 30:401-417

Dullinger S, Dirnböck T, Grabherr G (2004) Modelling climate change-driven treeline shifts: relative effects of temperature increase, dispersal and invasibility. J Ecol 92:241-252

Fan ZX, Brauning A, Cao KF, Zhu SD (2009) Growth-climate responses of high-elevation conifers in the central Hengduan Mountains, southwestern China. For Ecol Manag 258:306-313

Guisan A, Theurillat JP (2000) Assessing alpine plant vulnerability to climate change: a modeling perspective. Integr Assess $1: 307-320$

Hadley JL, Smith WK (1983) Influence of wind exposure on needle desiccation and mortality for timberline conifers in Wyoming, USA. Arc Alp Res 15:127-135

Hadley JL, Smith WK (1986) Wind effects on needles of timberline conifers: seasonal influence on mortality. Ecology 67:12-19

Harsch MA, Bader MY (2011) Treeline form-a potential key to understanding treeline dynamics. Glob Ecol Biogeogr 20:582-596

Harsch MA, Hulme PE, McGlone M, Duncan RP (2009) Are treelines advancing? A global meta-analysis of treeline response to climate warming. Ecol Lett 12:1040-1049

Hofgaard A, Kullman L, Alexandersson H (1991) Response of oldgrowth montane Picea abies (L.) Karst. forest to climatic variability in northern Sweden. New Phytol 119:585-594

Horikawa M, Tsuyama I, Matsui T, Kominami Y, Tanaka N (2009) Assessing the potential impacts of climate change on the alpine habitat suitability of Japanese stone pine (Pinus pumila). Landsc Ecol 24:115-128

Ishizuka K (1981) Damages on Abies mariesii by snow pressures in Mt Hakkoda. Ecological Studies on the Abies mariesii forest. Mt Hakkoda botanical lab, Tohoku Univ, Sendai, pp 39-48 (in Japanese)

Iverson LR, Prasad AM (1998) Predicting abundance of 80 tree species following climate change in the eastern United States. Ecology 68:465-485

Juntunen V, Neuvonen S, Norokorpi Y, Tasanen T (2002) Potential for timberline advance in northern Finland, as revealed by monitoring during 1983-99. Arctic 55:348-361
Kajimoto T (1995) Ecological characteristics of Pinus pumila with special reference to dry matter production and regeneration. Jpn J Ecol 45:57-72 (in Japanese)

Kajimoto T, Seki T, Ikeda S, Daimaru H, Okamoto T, Onodera H (2002) Effects of snowfall fluctuation on tree growth and establishment of subalpine Abies mariesii near upper forestlimit of Mt. Yumori, northern Japan. Arc Antarc Alp Res 34:191-200

Kelly AE, Goulden ML (2008) Rapid shifts in plant distribution with recent climate change. Proc Natl Acad Sci USA 105:11823-11826

Kira T (1948) On the altitudinal arrangement of climatic zones in Japan. Kanti-Nogaku 2:143-173 (in Japanese)

Kohyama T (1980) Growth pattern of Abies mariesii saplings under conditions of open-growth and suppression. Bot Mag Tokyo 93:13-24

Kohyama T (1983) Seedling stage of two subalpine Abies species in distinction from sapling stage: a matter-economic analysis. Bot Mag Tokyo 96:49-65

Kullman L (2010) One century of treeline change and stability-experiences from the Swedish Scandes. Landsc Online $17: 1-31$

Kullman L, Öberg L (2009) Post-little ice age tree line rise and climate warming in the Swedish Scandes: a landscape ecological perspective. J Ecol 97:415-429

Lenoir J, Gegout JC, Marquet PA, de Ruffray P, Brisse H (2008) A significant upward shift in plant species optimum elevation during the 20th century. Science 320:1768-1771

Liang E, Wang Y, Eckstein D, Luo T (2011) Little change in the fir tree-line position on the southeastern Tibetan Plateau after 200 years of warming. New Phytol 190:760-769

Lin D, Xia J, Wan S (2010) Climate warming and biomass accumulation of terrestrial plants: a meta-analysis. New Phytol 188:187-198

Mäkinen H, Nöjd P, Kahle HP, Newmann U, Tveite B, Mielikänen K, Röle H, Spiecker H (2002) Radial growth variation of Norway spruce (Picea abies (L.) Karst.) across latitudinal and altitudinal gradients in central and northern Europe. For Ecol Manag 171:243-259

Marr JW (1977) The development and movement of tree islands near the upper limit of tree growth in the southern Rocky Mountains. Ecology 58:1159-1164

Massaccesi G, Roig FA, Pastur GJM, Barrera MD (2008) Growth patterns of Nothofagus pumilio trees along altitudinal gradients in Tierra del Fuego, Argentina. Trees 22:245-255

Miyajima Y, Takahashi K (2007) Changes with altitude of the stand structure of temperate forests on Mount Norikura, central Japan. J For Res 12:187-192

Miyajima Y, Sato T, Takahashi K (2007) Altitudinal changes in vegetation of tree, herb and fern species on Mount Norikura, central Japan. Veg Sci 24:29-40

Morin X, Thuiller W (2009) Comparing niche- and process-based models to reduce prediction uncertainty in species range shifts under climate change. Ecology 90:1301-1313

Nagano S, Nakano T, Hikosaka K, Maruta E (2009) Needle traits of an evergreen, coniferous shrub growing at wind-exposed and protected sites in a mountain region: does Pinus pumila produce needles with greater mass per area under wind-stress conditions? Plant Biol 11(Suppl 1):94-100

Nakamoto A, Ikeda T, Maruta E (2012) Needle browning and death in Pinus pumila in the alpine region of central Japan were not related to mechanical damage of cuticle and cuticle thickness. Can J For Res 42:167-178

Nakamoto A, Ikeda T, Maruta E (2013) Needle browning and death in the flagged crown of Abies mariesii in the timberline ecotone of the alpine region in central Japan. Trees 27:815-825

Natori Y, Matsuda Y (1966) The age and the thickening growth of Pinus pumila Regel on Mt. Norikura in Honshu, Japan. Jpn J Ecol 16:247-251 (in Japanese)

Okitsu S, Ito K (1983) Dynamic ecology of the Pinus pumila community of Mts. Taisetsu, Hokkaido, Japan. Environ Sci Hokkaido Univ 6:151-184 (in Japanese) 
Okitsu S, Ito K (1984) The relation of forest limit to the WI15 in mountains of Hokkaido. Jpn J Ecol 34:341-346 (in Japanese)

Okitsu S, Mizoguchi T (1991) Cone production of Pinus pumila scrubs. Jpn J Ecol 41:101-107 (in Japanese)

Paulsen J, Weber UM, Körner C (2000) Tree growth near treeline: abrupt or gradual reduction with altitude? Arc Antarc Alp Res 32:14-20

Peltola H, Kellomäki S, Väisänen H, Ikonen VP (1999) A mechanistic model for assessing the risk of wind and snow damage to single trees and stands of Scots pine, Norway spruce, and birch. Can J For Res 29:647-661

Peng J, Gou X, Chen F, Li J, Liu P, Zhang Y (2008) Altitudinal variability of climate-tree growth relationships along a consistent slope of Anyemaqen Mountains, northeastern Tibetan Plateau. Dendrochronologia 26:87-96

Saito M, Irie M (2002) Meteorological observations at Norikura Solar observatory. Rep Nat Astronom Observ Japan 6:37-47 (in Japanese)

Sakai A, Matsui K, Kabeya D, Sakai S (2003) Altitudinal variation in lifetime growth trajectory and reproductive schedule of a sub-alpine conifer, Abies mariesii. Evol Ecol Res 5:671-689

Savva Y, Oleksyn J, Reich PB, Tjoelker MG, Vaganov EA, Modrzynski J (2006) Interannual growth response of Norway spruce to climate along an altitudinal gradient in the Tatra Mountains, Poland. Trees 20:735-746

Scott PA, Bentley CV, Fayle DCF, Hansell RIC (1987) Crown forms and shoot elongation of white spruce at the treeline, Churchill, Manitoba, Canada. Arc Alp Res 19:175-186

Scott PA, Hansell RIC, Erickson WR (1993) Influences of wind and snow on northern tree-line environments at Churchill, Manitoba, Canada. Arctic 46:316-323

Seki T, Kajimoto T, Sugita H, Daimaru H, Ikeda S, Okamoto T (2005) Mechanical damage on Abies mariesii trees buried below the snowpack. Arc Antarc Alp Res 37:34-40

Sutinen R, Närhi P, Middleton M, Hänninen P, Timonen M, Sutinen ML (2012) Advance of Norway spruce (Picea abies) onto mafic Lommoltunturi fell in Finnish Lapland during the last 200 years. Boreas 41:367-378

Takahashi K (1996) Plastic response of crown architecture to crowding in understorey trees of two co-dominating conifers. Ann Bot 77:159-164

Takahashi K (1997) Regeneration and coexistence of two subalpine conifer species in relation to dwarf bamboo in the understorey. J Veg Sci 8:529-536

Takahashi K (2003) Effects of climatic conditions on shoot elongation of alpine dwarf pine (Pinus pumila) at its upper and lower altitudinal limits in central Japan. Arc Antarc Alp Res $35: 1-7$

Takahashi K (2005) Effects of artificial warming on shoot elongation of alpine dwarf pine (Pinus pumila) on Mt. Shogigashira, central Japan. Arc Antarc Alp Res 37:620-625

Takahashi K (2006) Shoot growth chronology of alpine dwarf pine (Pinus pumila) in relation to shoot size and climatic conditions: a reassessment. Polar Biosci 19:123-132
Takahashi K (2010) Effects of altitude and competition on growth and mortality of the conifer Abies sachalinensis. Ecol Res 25:801-812

Takahashi K, Okuhara I (2013) Forecasting the effects of global warming on radial growth of subalpine trees at the upper and lower distribution limits in central Japan. Clim Change 117:273-287

Takahashi K, Yoshida S (2009) How the scrub height of Pinus pumila decreases at the treeline. Ecol Res 24:847-854

Takahashi K, Azuma H, Yasue K (2003) Effects of climate on the radial growth of tree species in the upper and lower distribution limits of an altitudinal ecotone on Mt. Norikura, central Japan. Ecol Res 18:549-558

Takahashi K, Tokumitsu Y, Yasue K (2005) Climatic factors affecting the tree-ring width of Betula ermanii at the timberline on Mount Norikura, central Japan. Ecol Res 20:445-451

Takahashi K, Okuhara I, Tokumitsu Y, Yasue K (2011) Responses to climate by tree-ring widths and maximum latewood densities of two Abies species at upper and lower altitudinal distribution limits in central Japan. Trees 25:745-753

Takahashi K, Hirosawa T, Morishima R (2012) How the timberline formed: altitudinal changes in stand structure and dynamics around the timberline in central Japan. Ann Bot 109:1165-1174

Tanaka N, Nakazono E, Tsuyama I, Matsui T (2009) Assessing impact of climate warming on potential habitats of ten conifer species in Japan. Earth Environ 14:153-164 (in Japanese)

Thomas SC (1996) Asymptotic height as a predictor of growth and allometric characteristics in Malaysian rain forest trees. Am J Bot 83:556-566

Thomas SC (2011) Age-related changes in tree growth and functional biology: the role of reproduction. In: Meinzer FC, Lachenbruch B, Dawson TE (eds) Size- and age-related changes in tree structure and function. Springer, Dordrecht Heidelberg London New York, pp 33-64

Thuiller W, Lavorel S, Araujo MB, Sykes MT, Prentice C (2005) Climate change threats to plant diversity in Europe. Proc Natl Acad Sci USA 102:8245-8250

Tranquillini W (1979) Climatic resistance and damage of trees at timberline. In: Physiological ecology of the alpine timberline. Springer, Berlin Heidelberg New York

Wardle P (1968) Engelmann spruce (Picea engelmannii Engel.) at its upper limits on the Front Range, Colorado. Ecology 49:483-495

Wardle P (1977) Japanese timberlines and some geographic comparisons. Acr Alp Res 9:249-258

Wardle P (1985) New Zealand timberlines. 1. Growth and survival of native and introduced tree species in the Craigiebun Range, Canterbury. N Z J Bot 23:219-234

Yamanaka M, Saito K, Ishizuka K (1973) Historical and ecological studies of Abies mariesii on Mt. Gassan, the Dewa Mountains, northeast Japan. Jpn J Ecol 23:171-185

Yoshino MM (1973) Wind-shaped trees in the subalpine zone in Japan. Arc Alp Res 5:A115-A126

Zhang Y, Xu M, Adams JM, Wang X (2009) Can Landsat imagery detect tree line dynamics? Int J Remote Sens 30:1327-1340 